\title{
A Study on Guidelines of Tourism Development in Korea and Japan
}

\author{
Won-Jo Jung* $\cdot$ Han-Seok Lee ${ }^{* *}+$ †yung-Kwon Lee \\ * Sangji Environment \& Architects Inc., Busan 600-712, Korea \\ ** Division of Architect \& Ocean Space, National Korea Maritime University, Busan 606-791, Korea \\ + Division of Architect \& Ocean Space, National Korea Maritime University, Busan 606-791, Korea
}

\begin{abstract}
Fishing village is becoming the central base of fishing industry and it plays a major role. However, there is a decrement of marine resources and some difficulties with the deterioration of fishing industry management. In order to solve these problems, there should be some developments(e.g. fishing village toursim development) on various undergoing government and the private organization programs. Nevertheless, there are not guidelines for fishing village tourism development to utilize for practical business. Therefore, it is necessary to understand the current status and guidelines regarding the development of fishing village for coastal planner. The primary purpose of this study is to investigate the characteristics of fishing village development works in Korea and Japan. The second purpose is to identifie success factors after analyzing individual success cases. Based on evidence from the literature and a dialogue with village leader, a literature review on extracting success cases for guidelines were selected according to criteria such as the degree of contribution to an increase in income of the fishing village, the degree of contribution to an increase in consumption of marine products using local natural resources, the number of tourists that visits the village. Finally we propose guidelines for future fishing village development projects. The guidelines based on the successful cases, as well as the major factors about the objectives and direction of fishing village tourism development, suggested as follows. 1)Plans for land use, 2)Development of tourist resources, 3)Plans for views, 4)Plans for resource protection, 5)Plans for operation and marketing.
\end{abstract}

Key words : fishing village, tourism, community building business, coastal development

\section{Introduction}

In the case of South Korea, an initiative is underway under the lead of the South Korean government to create an integrated coastal and ocean space for production, residency, and tourism with the aim of providing opportunity for income and creating workplaces for fishermen through the development of fishing village tourism. The South Korean government has developed comprehensive measures to promote the development of fishing village tourism and is in the process of pursuing a multilateral policy of development of a model integrating the fishing port and fishing village development projects.

Japan has a long history of development of fishing villages and has come to the stage of redevelopment. The present status is that the Fisheries Agency of Japan has an annual budget for fisheries sector is 300 billion yen, of which 200 billion yen is allocated for investments in the development of fishing ports. In 1998, all the fishing ports across the nation were re-evaluated to analyze and assess the economic viability in support of the development of future fishing ports.

\footnotetext{
* wj.wjjung@hanmail.net 051)240-0023

** hansk@kmou.ac.kr 051)410-4581

† Corresponding author : mklee@kmou.ac.kr 051)410-4584
}

\subsection{Concept of Fishing Village Tourism}

The concept of fishing village tourism was first introduced by S. Kim of Korea Maritime Institute in 2001. Since then, it was applied to many fishing villages so that providing good services to tourists, promoting regional development, improving residents lives and so on.

However, the concept of fishing village tourism has not yet clearly been defined, and fishing village tourism is often confused with marine tourism, coastal tourism, or island tourism. Also, tide-lands, which constitute a part of fishing village tourism, is often confused as part of ecological tourism(Lim,2004). In this study, fishing village tourism is defined to mean the activities to revitalize local fishing villages through the promotion of interchanges between city residents and fishing village residents by utilizing the accommodations operated by a fisherman's family, as well as the various tourism resources, such as the life, culture, and natural resources of fishing villages.

According to Kim, S. et al.(2001), the scope of fishing village tourism can be summarized as follows. 
First, fishing village tourism shall be the tourism activities that can be conducted at fishing villages. Sea bathing cannot be included as part of the scope of fishing village tourism unless done at the bathing beach in a fishing village. In some cases, marine sports, such as yachting and windsurfing, may not be included as part of fishing village tourism depending on locations. But from the perspective of this first point, it may be appropriate to include some marine sports activities as part of the scope of fishing village tourism by positioning fishing village tourism as a subordinate concept of marine tourism.

Second, fishing village tourism shall be tourism activities that can be linked to a substantial portion of a fisherman's income. This is the reason fishing village tourism heavily emphasizes the policy initiative to provide income sources outside fisheries to fishermen.

Third, fishing village tourism shall be the tourism activities that are directly or indirectly linked to fishery activities in fishing villages and by fishermen. These activities include using part of fishery activities as tourism (in case of experience-type tourism), using fishing boats for use by fishermen, utilization of fishing ports and the surface of seawater and use of facilities operated by fishermen such as accommodation and eateries.

With all these things considered, fishing village tourism can be defined to mean all the activities related to tourism, leisure, and sports utilizing those resources that would exist in the coastal and ocean space in a fishing village such as the sea, small islands and beaches. In terms of the resources for fishing village tourism, natural resources include bathing beaches, tidelands, habitats for migratory birds, and fishing spots. On the other hand, cultural resources include local festivals, local specialties, local food, historical sites, fishing ports, fishing grounds, and boats.

\subsection{Characteristics of Fishing Village Tourism1)}

Fishing village tourism is mainly conducted by fishermen. As the fishermen are still engaged in fishing as their main business, fishing village tourism has various advantages, such as these fishermen having strong attachments to and relevant knowledge about local areas. On the other hand, it has its limitations because the fishermen cannot acquire the level of expertise about tourism that tourism operators usually have.

As fishing village tourism is operated by fishermen by utilizing mainly local resources, the business scale and invested capital tend to be small. Smallness is one of the limitations inherent in this type of tourism operation. However, fishing village tourism has the advantage of being able to generate substantial results if properly operated by taking the best advantage of geographical conditions.

Fishing village tourism starts from a pure fishing village, evolves into fishing village tourism equipped with various recreational facilities, and then further develops into a touristy fishing village(Kim et al., 2001; Kim, 2007). In terms of the spatial structure of fishing village tourism, natural resources, such as the hinterlands, beaches, and seas can be utilized in combination. In terms of the time structure, seasonally unique fishing and other natural phenomena can be utilized as tourism resources.

\subsection{Present State of Fishing Village Tourism}

As tourism has globally become more diversified and specialized, greater emphasis has come to be placed on an experience-type tourism product. Accordingly, there has been an ongoing shift to marine tourism and away from inland-centric tourism. That is, due to the increase in tourism demand, the form of tourism has gradually become more diversified, causing a shift in marine tourism from the traditional form centering on bathing beaches to a more diversified form. Also, there has been a substantial increase in the number of tourists visiting fishing villages, and the development of fishing village tourism is in progress, centering on those fishing villages that have been revitalized through the implementation of infrastructure development projects such as fishing ports.

In the case of South Korea, the development of fishing village tourism originated with the fishing village tourism development project initiated by the Ministry of Maritime Affairs and Fisheries during the period of 1990 to 1996. Since 1994, out of the Ministry's investment budget for the Overall Fishing Village Development Project, substantial investments have been

1) Source: Ministry of Maritime Affairs and Fisheries of South Korea(2001), Research on Establishment of Midterm and Longterm Development Plan for Fishing Village Tourism, p. 21 
directed toward the fishing village tourism sector. The Overall Fishing Village Development Project includes fishing village tourism and leisure complex development projects, construction of fishing village folk museums, and development of experience-type fishing village tourism. Various projects for fishing village tourism infrastructure development are presently in progress under the sponsorship of the South Korean government, and they are still in the early stages. But, most of the completed portions of these projects have already taken root in the local society and have started to contribute to income growth of the people in the fishery industry in the area, as well as to providing more tourism and leisure opportunities for city residents.

In the case of Japan, it is stipulated in the Fisheries Basic Act of 2001 that one of the basic policies for the fishery industry and fishing villages is "enhancement of multifunctional measures." The background and intent of that particular policy is obviously the development of marine tourism and marine recreational activities. Marine tourism and marine recreational activities have grown so much in recent years and now are collectively called "blue tourism." Blue tourism includes marine tourism, marine recreational activities, and marine sports. There are a wide range of ways that the fishermen's union and fishermen themselves cope with the boom of blue tourism-ranging from taking passive attitudes as the managers of fisheries rights to positively promoting an understanding of the fisheries industry through implementation of the "experience and learn fisheries" programs. There is a tendency toward diversification in the way the fishing villages interact with city residents ${ }^{2}$.

\section{Method}

This paper is intended to summarize the list of suggestions for future fishing village tourism development projects through the analyses of the best practices of fishing village development projects in both South Korea and Japan and the subsequent identification of success factors. In addition, we investigate the characteristics of fishing village development projects in both these countries, and present guidelines for future fishing village development projects.

In addition, the best practices cited in this section cover the fishing villages in Japan and South Korea and have been selected in consideration of the following factors: the degree of contribution to an increase in income of the fishing village, the degree of contribution to an increase in consumption of marine products using local natural resources, the number of tourists to the village. The selection has been made based on the results of interview surveys with the people concerned and government publication materials.

Table 1 Summary of surveys

\begin{tabular}{|c|c|c|c|}
\hline & period & method & object \\
\hline $\begin{array}{l}\text { pre- } \\
\text { survey }\end{array}$ & $\begin{array}{l}\text { Apr. } 2008 \\
\sim \text { Jul. } 2008\end{array}$ & $\begin{array}{l}\text { literature } \\
\text { review }\end{array}$ & $\begin{array}{l}\text { government \& research } \\
\text { institute publication* }\end{array}$ \\
\hline \multirow[t]{2}{*}{$\begin{array}{l}\text { main } \\
\text { survey }\end{array}$} & $\begin{array}{l}1^{\text {st. }} \text { Aug. } 2008 \\
2^{\text {nd. }} \text { Mar. } 2009 \\
3^{\text {rd: }} \text { Oct. } 2009\end{array}$ & interview & $\begin{array}{l}\text { ·local government } \\
\text { (officer) } \\
\text { ·public research institute } \\
\text { (research scientist) } \\
\text { fishing village chief, } \\
\text { village producer, } \\
\text { village coordinator }\end{array}$ \\
\hline & $\begin{array}{l}1^{\text {st }}: \text { Mar. } 2009 \\
2^{\text {nd }}: \text { Oct. } 2009\end{array}$ & $\begin{array}{l}\text { field } \\
\text { survey }\end{array}$ & $\begin{array}{l}\text { · Korea: Songgye, Mira, } \\
\text { Jeodo } \\
\text { · Japan : Hota, Hagi }\end{array}$ \\
\hline
\end{tabular}

*1. The Ministry of Maritime Affairs and Fisheries of South Korea(2007), Collection of Best Practices in Fisheries Industry and Fishing Village Projects. 2 Kyonan Town, Chiba prefecture(2008), Hota Fishing Port Area Activation Plan. 3 Kyonan Town, Chiba prefecture(2008), Hota Fishing Port Area Activation Plan.
Shoko Research Institute (2007), Report of Hagi Sea Mart Business Model, Shoko Research Institute (2007), Report of Hagl Sea Mart Business Model, 4.
Ministry of Land, Infrastructure Transport and Tourism(2010), Japan Tourism Ministry of Land, Intrastructure Transport and Tourism(2010)
Agency Policy: Human Resource Development and Utilization

\section{Results}

\section{1 Best Practices of Fishing Village Tourism ${ }^{3}$}

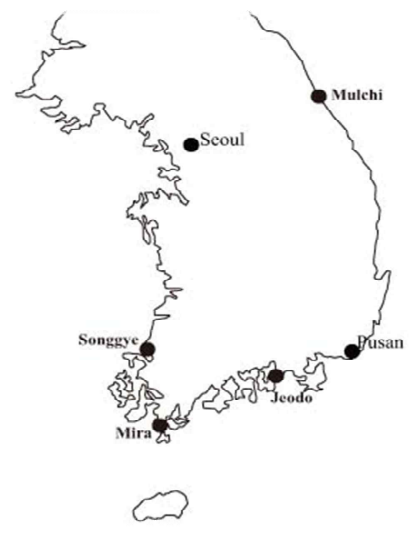

Fig. 1 Locations of Fishing Village in South Korea

2) Source : Norinchukin Research Institute, The Present Conditions and the Problem of the Marine Products Market

3) Source (Case1-4): The Ministry of Maritime Affairs and Fisheries of South Korea(2007), Collection of Best Practices in Fisheries Industry and Fishing Village Projects. 
1) Mulchi Fishing Village in South Korea

The foundation of the Mulchi fishing village's success has been laid through the Overall Fishing Village Development Project sponsored by the South Korean government. The fishermen earn an average income (excluding income from fishery industry) of 100 million South Korean won or more per store at the Sashimi (sliced raw fish) Center, housed in a three-storied building. The fishing Village Cooperatives Development Fund has been created based on such incomes. The Fund has re-invested in the facilities, earning additional lease incomes and subsequently leading to the construction of the Fishing Village Cooperatives Building at its own expense. This project has served as a driving force for the development of this area.

In addition, because each store operator is engaged in fishing, the operator can sell to tourists at inexpensive prices those fresh fisheries products that the person directly catches or grows. As part of the initiatives to provide a comfortable environment for customers, the customer service center is established with the aim of resolving customer complaints and eliminating inconveniences for Center visitors. In order to maintain order at the center and to enhance customer services, the Rules for Maintaining Order at the Live Fish Center have been prepared, and all the members of the Mulchi fishing village cooperatives are required to abide by the Rules. Rule violators have faced severe sanctions such as business suspension. The Rules also cover the management and operation of the Live Fish Sashimi Center. As there is an appreciable difference in store sales between the second floor and the third floor, no members of the fishing village cooperatives are willing to set up stores on the third floor. In order to resolve this issue, the Rules specify that the locations of stores will rotate every year between the second and third floors. An important success factor is the elimination of the factors in internal conflicts by adopting a rational facilities management method. In the Mulchi fishing village, they do not establish a separate organization dedicated to the management and operation of the Live Fish Sashimi Center but use the Fishing Village Cooperatives to do the management and operation.

The important factors for the success of the Mulchi fishing village can be cited as follows: dedicated efforts by the president of the Fishing Village Cooperatives, leadership by the cooperatives president to provide direction, effect of real income earned outside fisheries as a result of following the directions presented, rational decision-making system through discussions, and the relationship of trust and solidarity among the cooperative members nurtured over time through such a decision-making system. The most important facility of the fishing village's tourism item is Mulchi Raw Fish Center in Mulchi fishing village. In the case of Raw Fish Center, it directly operate in Mulchi fishing village cooperatives. However this center has been built more than 10 years. Therefore it need to do full re-modeling.

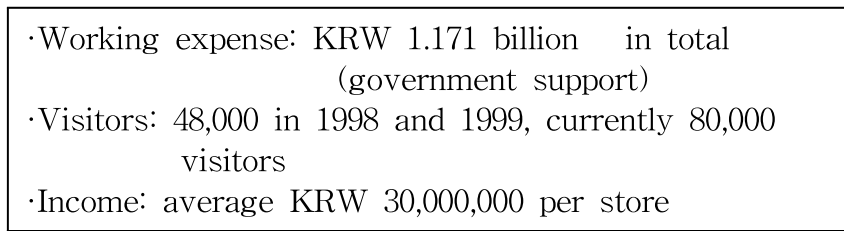

\section{2) Songgye Fishing Village in South Korea}

In the case of Songgye fishing village, the success can be attributed to enhancement of the satisfaction index of tourists participating in experiential tourism programs by making the best utilization of the diversity and overflowing richness of its natural resources. Thanks to its tidelands endowed with abundant natural ecological resources and the superb resilience of these ecological resources, the Songgye fishing village has attained the level of success that nearly fills its capacity over a short period of time since the inception of business. The fishing village residents made dedicated efforts in order to effectively utilize these vast tideland resources, and the cooperatives president and young members Worked positively toward the project-it is believed that these two factors have caused and provided strategic directions toward the development and expansion of the project utilizing traditional natural resources.

Also, in order to provide further improved services in its experiential fisheries tourism programs, the cooperatives president and members voluntarily participated in the education programs related to agricultural experience tourisms intended for village leaders and residents by receiving counseling from the experts of the Korea Tourism Organization. Such education programs included the Fishing Village Tourism Leader/Guide Education, the Experience Type Tourism Leader Program for Agricultural Villages, Mountain Villages and Fishing Villages, and Agricultural Village Tourism Leader Education. Most likely it would be 
difficult to promote the fishing village tourism project under the management of the Fishing Village Cooperatives if the cooperatives were to fail to offer even a minimal shared

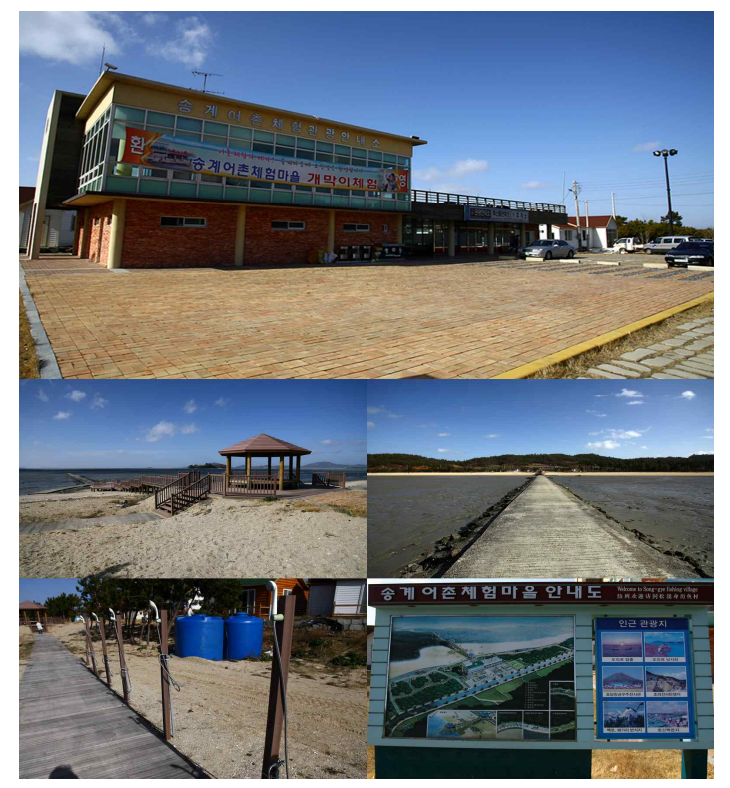

Fig. 2 Field Survey of Songgye Fishing Village (Photo by Wonjo Jung)

portion of such a project to non-fishing village cooperatives members of the community. In anticipation of such a potential backlash, special consideration was given so that non-cooperative residents could participate in the experiential tourism programs and income generating programs. This helped build a cooperative relationship among the community residents during the process of consensus building in support of various infrastructure-building projects. This is one of the key success factors. The fishing village's tourism facility, which is introduced in Songgye fishing village, is Songgye Experience Tourism Information Center and Seafood Speciality Stores. Also, mud flat experience ground, laver dry experience ground and salt farm experience ground are serviced to visitors.

\begin{tabular}{|c|c|}
\hline -Working & $\begin{array}{l}\text { expense: } \text { KRW 500million in total } \\
\text { (government: KRW } 250 \text { million, } \\
\text { county office: KRW } 250 \text { million) }\end{array}$ \\
\hline - Visitors: & $\begin{array}{l}55,000 \text { before development, currently } 110,000 \\
\text { visitors }\end{array}$ \\
\hline Income: & $\begin{array}{l}\text { KRW 500million (creation of new income in } \\
\text { tourism industry), Annual employment effect } \\
\text { equivalent to } 825 \text { people for business } \\
\text { management }\end{array}$ \\
\hline
\end{tabular}

\section{3) Jeodo Community in South Korea}

In the case of Jeodo fishing village, the success can be attributed to the bond of solidarity and strong will of the village residents. The Jeodo fishing village initiated the project based on the unanimous consent of all the residents and directly invested in the project. In addition, a long-range strategy planning was another factor for the success. All the village residents participated in the self-regulated community and set up a steering committee. In order to improve the efficiency of fishing and harvesting work by using a surveillance boat owned by the self-regulated community, a protected water surface was established for control purposes with the full participation of all the self-regulated community members. Also, a lookout post was established to continue surveillance to protect and manage clean fishing grounds and marine resources.

The South Korean government played a major role in the success of this Jeodo fishing village. The Jeodo fishing village adopted the self-regulated fishing business promoted by the Ministry of Maritime Affairs and Fisheries of South Korea (MMAF). Since 2001, the MMAF has started to promote the self-regulated fishing business as a campaign in which fishermen autonomously participate in and implement building infrastructure to support a sustainable and productive fishery industry, control and manage fishing grounds and marine resources, improve operating efficiency, and maintain order to help achieve income growth and fishing industry development. The fishing village tourism facilities, which are introduced in Jeodo community, are lodging facilities utilized closing school, fishing place, fishing ground monitoring guard post, etc.

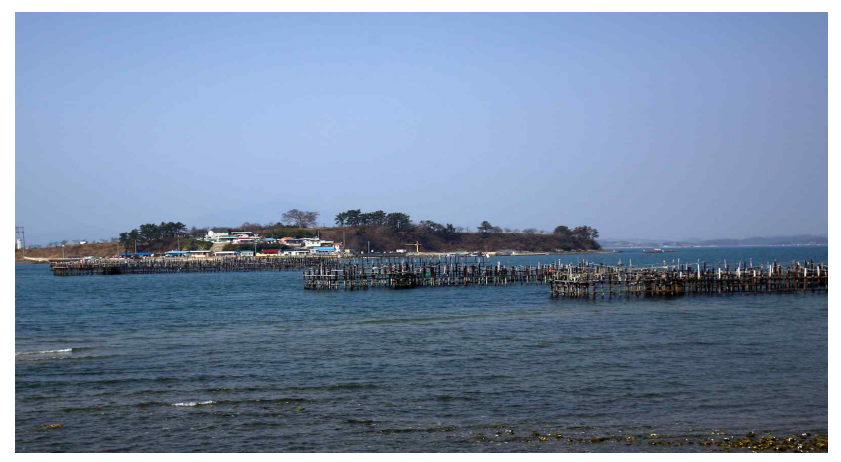

Fig. 3 Field Survey of Jeodo Fishing Village (Photo by Wonjo Jung) 


\begin{tabular}{|c|}
\hline $\begin{array}{l}\text {-Working expense: KRW 450million in total } \\
\text { (independent fund KRW } 146 \text { million) } \\
\text {-Visitors: } 3,000 \text { in } 2004,6,000 \text { in } 2005,20,000 \text { in } 2008 \\
\text { - Income:short-necked clam farm: average } \\
\text { production } 700 \text { ton, net income of KRW } \\
700 \text { million (before development: production } \\
300 \text { ton, net income of KRW } 320 \text { million), } \\
\text { Annual income from other source than } \\
\text { fishing: KRW } 100 \text { million }\end{array}$ \\
\hline
\end{tabular}

\section{4) Mira Community in South Korea}

The best practice in the Mira self-regulated community deals with the case example in which the combined income from the abalones farmed and caught by each individual fisherman were maximized through joint distribution and sales.

The community attempted to resolve the issues or at least minimize the negative impacts by taking the following steps-expanded abalone farming, established the fisheries standards, implemented the project for redeveloping the related facilities to support production of fisheries products, and determined the order of shipments through discussions and agreement so that the shipment of fisheries products by those fishermen having financial difficulties could be prioritized.

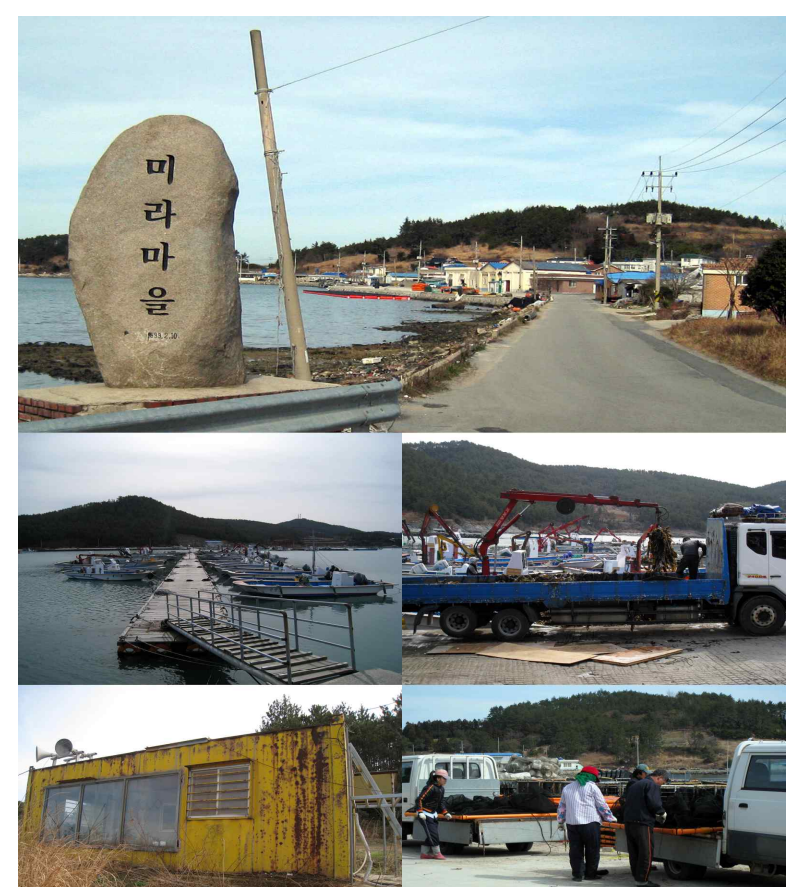

Fig. 4 Field Survey of Mira Fishing Village (Photo by Wonjo Jung)

Also, $0.2 \%$ of the sales amount was set aside as the public fund to finance the operation and management of direct sales stores. The staff of the Nowha fishery cooperatives kept the shipment records 365 days a year to help secure transparency of the joint distribution and sales as well as to help ship products of standardized quality, such as price per size, ensuring the reliability of products. In 2000, a village self governing act and autonomous management committee were established, with revision to the previous regulations, in order to distribute fishery among fishing village community in an equal manner. In 2002, autonomous management committee was organized for farming of abalone, consolidating the previous organizations into a single entity. In 2003, independent fund in amount of KRW 300 million was set up, and distribution of fishery for individuals was completed by reorganizing the fishing ground. In the same year, the community was chosen as autonomous management community by the government, and received KRW 200 million in subsidy. In 2005, the grant was extended with additional KRW 300 million, which was used to establish infrastructure for joint sales of abalone. The number of abalone farming households increased from 10 in 1992, 20 in 1998, 60 in 2002 to 76 in 2006 as the old folks and their children began to return to the village following revitalization of abalone farming. The fishing village tourism facilities, are which introduced in Mira community, are abalone market, fishing ground monitoring guard post, etc.

\begin{tabular}{|c} 
·Working expense: government support KRW 500 \\
million, village fund 300 million \\
·Visitors: 55,000 before development, currently 110,000 \\
visitors \\
-Income: \\
average KRW 100 150 million per each \\
fishing household, Sales volume and \\
amount of abalone(400ton, KRW 150 million \\
in 2005,380 ton, KRW 114 million in 2006)
\end{tabular}

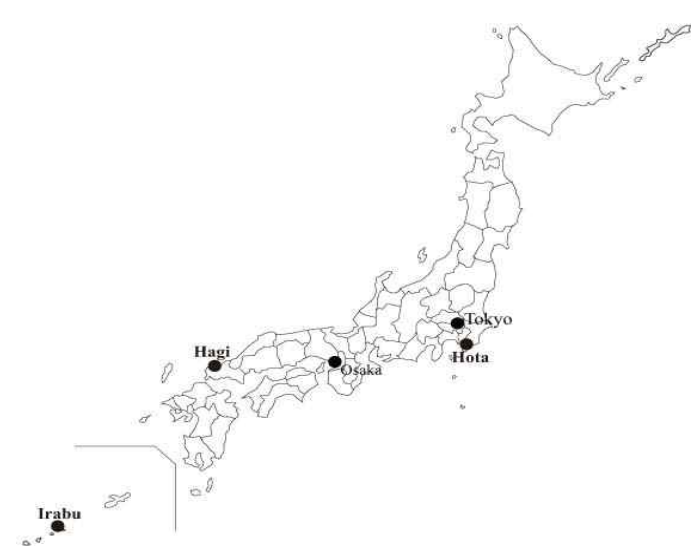

Fig. 5 Locations of Fishing Village in Japan 


\section{5) Hota Fishing Village in Japan4)}

Since 1995, many people have visited, for inspection purposes, the Seafood-Promoting Restaurant Banya operated directly by the Hota fishing cooperatives and the town of Kyonan as an advanced region for interaction between the fishing village and the city. The Banya restaurant represents the new coinage "Umigyo" in Japanese or the marine industry combining sea-related primary and tertiary industries by utilizing sea and marine resources. With the Banya restaurant, the fishermen now can cook and sell the fractions of products that do not fit the lot requirement, which they previously could not ship for sales. The Banya restaurant has made it possible to realize the more effecttive utilization of marine resources and prevent the lowering of the prices of fisheries products by adding value, thus contributing to the financial stability of fishery industry operation.

The Banya restaurant accepts reservations for meals that meet customer needs and can accommodate large tour buses. With the opening of Banya restaurant No. 3, 76 large tour buses were accepted, with the total number of visitors at 4,364 per year (a year-over-year increase of 24\%). Some of the comments from the visitors at Banya restaurant No. 3 include "I usually come to this area on a large tour bus so I could not come here before because they did not allow the tour bus to park. I am really happy because I can eat delicious fresh seafood here." and "Previously I had to wait for about one hour to eat. But now, because I can make reservations in advance, I can eat my food without waiting. That helps me map out the plan for my day." The fishing village's tourism facilities, which are introduced in Hota fishing village, are seafood restaurant, restaurant for exclusive use of the group tourist, seafood speciality stores, souvenir store, the accommodations, hot spring inn, boat berthing facilities, et cetera. In addition, the Hota fishing village cooperatives operate a fixed shore net fishing experience tourism, a semisubmarine boat.

Working expense: 192 million yen

Visitors: 200,000 visitors for a year

Income: average 338 million yen
6) Hagi Fishing Village in Japan5)

In April 2001, the Yamaguchi-Hagi Fisheries Cooperatives was inaugurated by merging 14 fisheries cooperatives in Hagi city and Abu county, resulting in an integration of various fish markets separated by fish species in the area into one new comprehensive fish market. In line with these moves, the Hagi Seaside

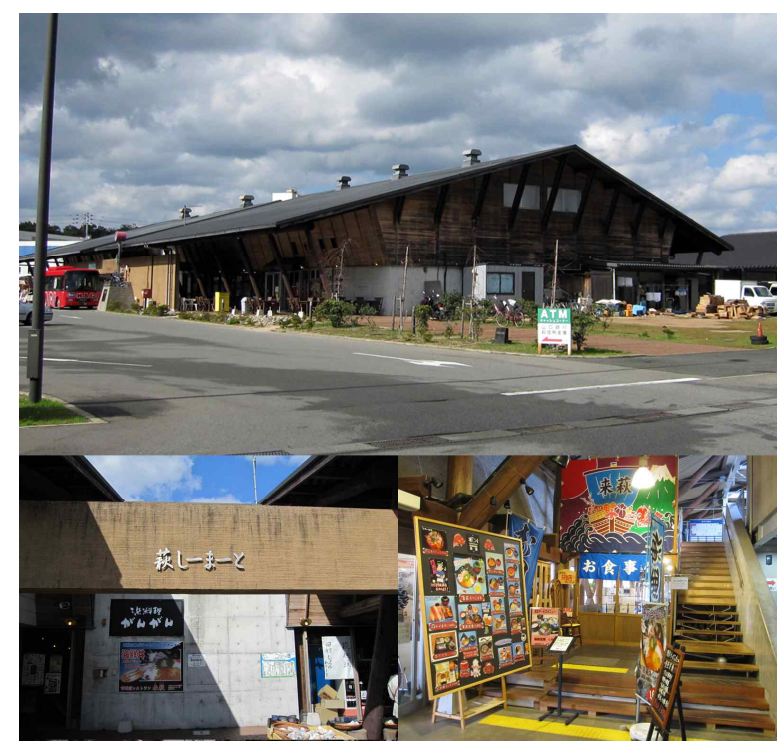

Fig. 6 Field Survey of Hagi Fishing Village (Photo by Wonjo Jung)

Market (the Market) was established as a strategic base camp to promote local fisheries products to tourists and local residents. The Market is being operating by the Hometown Furusato Hagi Food Cooperative Corporation organized by the operators of fisheries and agricultural products. These operators set up stores in the Market. Most of the core staff of the Hagi Food Cooperative Corporation have come from private companies through the process of open recruitment across the country and have introduced objective viewpoints from the outside looking in about the operation and management of related facilities. The establishment of the Market was a grant-aide project accredited by the Integrated Food Commerce Facilities Development Project and the Food Sales and Distribution Modernization Project (both sponsored by the Ministry of Agriculture, Forestry, and Fisheries in 2000), and by the Michinoeki (or Roadside Station)

4) Source: Kyonan Town, Chiba prefecture(2008), Hota

Fishing Port Area Activation Plan

5) Source: Nakasawa, S.(2007), Report of Hagi Sea Mart

Business Model, Shoko Research Institute 
(sponsored by the Ministry of Land, Infrastructure Transport and Tourism). In the opening year of 2001, about 1.5 million people visited the Market, presumably contributing to the increase in the aggregate number of tourists visiting the city of Hagi.

Also, the prices of fisheries products sold at the Market are targeted to be set at the same levels as local supermarkets. This encourages many local residents to shop at the Market on weekdays, alleviating the differences in the number of visitors to the Market between weekdays and weekends and thus helping stabilize management of the Market.

The restaurant attached to the Market features food using local products and is crowded with local residents during weekdays. An attempt has been made to make the local products well established as tourism resources by promoting public relations activities for its local food culture to tourists and by providing opportunities for local residents to enjoy those local fisheries products that they could not eat previously.

The fishing village's tourism facilities, which are introduced in Hagi fishing village, are Hagi sea market, Local seafood stores, seafood restaurant, etc.

-Working expense: approximately 500 million yen
(government support 33 percent)
-Visitors: $\begin{gathered}1,500,000 \text { in } 2001, \quad \text { currently } 1,400,000 \\ \text { visitors }\end{gathered}$
-Income: $\begin{gathered}840 \text { million yen in } 2006 \text {, average } 800 \text { million } \\ \text { yen }\end{gathered}$

\section{7) Irabu Fishing Village in Japan6)}

With the opening of the School of Ocean in 1995, the Iheya Island became the high profile topics through the words of mouth of the participants and the coverage by the mass media. The Okinawa Convention \& Visitors Bureau was flooded with inquiries about the Iheya Island, prompting them to put the island on the tourist map of Okinawa Prefecture. The School of Ocean, which started with the Iheya village, now includes three other schools - the Miyako-Irabu branch school in Irabu village, the Kunigami school in Kunigami village, and the Yanbaru school in Ginoza village. The number of attendants in the School of Ocean increased to 600 in 2003 from 60 in 1995, with the number of group participants at 9 and the cumulative total attendants at more than 2,000. Each of these four Schools of Ocean is conducting its own activities by utilizing its own characteristics of nature and traditional cultures.

In terms of the ripple effects to the regional economies, a total of more than 2,000 people have participated to date in the School of Ocean held in the Iheya village. The ripple economic effects to the local tourist accommodation facilities have been significant as all these attendants stay at the local guest houses, etc. affiliated with the School of Ocean. The participation of local fishermen and the fishery cooperatives staff in the Schools of Ocean not only provides a stable opportunity for giving subsidiary businesses to the people engaged in the fisheries industry but also leads to providing incremental revenues to the local fisheries cooperatives. The School of Ocean generates additional combined revenue of nearly 10 million yen per year to the fishermen and guest house operators in the Iheya village. To date the Schools of Ocean have received a total of more than 200 coverages from televisions, radios, newspapers, magazines, and PR publications, thus contributing to enhancement of the publicities of the Iheya villages and other sponsoring villages. Due to the effect of the School of Ocean, about 10 people have come to settle down in the Iheya village from outside the village. The fishing village's tourism facilities, which are introduced in Irabu fishing village, are a Camping Ground, lodgment, seafood restaurant, etc. In addition, the Irabu fishing village cooperative operates experience-based classroom including a seaweed harvest, an octopus capture, a clam transplant, etc.

-Working expense: 2 billion yen

-Visitors: 60 in 1995, 600 in 2003, currently 2,000 visitors

-Income: average 10 million yen

6) Source: Ministry of Land, Infrastructure Transport and Tourism(2010), Japan Tourism Agency Policy: Human Resource Development and Utilization 
Table 2 Analysis of Successful Cases

\begin{tabular}{|c|c|c|}
\hline Case & Location & Successful Cases \\
\hline $\begin{array}{l}\text { Mulchi } \\
\text { Fishing } \\
\text { Village }\end{array}$ & $\begin{array}{l}\text { Ganghyeon } \\
\text {-myeon, } \\
\text { Yangyang-g } \\
\text { un, } \\
\text { Gangwon-do } \\
\text { Korea }\end{array}$ & $\begin{array}{l}\text { - Best geographical conditions } \\
\text { - Fresh seafood is sold at reasonable price } \\
\text { - Voluntary effort to maintain pleasant environment with } \\
\text { visitor-oriented thinking } \\
\text { - Maximization of development of fishing village community through } \\
\text { re-investment } \\
\text { - Logical management } \\
\text { - Collaboration among community people centered on fishing village } \\
\text { chief }\end{array}$ \\
\hline $\begin{array}{l}\text { Songgy } \\
\text { e } \\
\text { Fishing } \\
\text { Village }\end{array}$ & $\begin{array}{l}\text { Songseok-ri, } \\
\text { Haeje-myeo } \\
\text { n, } \\
\text { Muan-gun, } \\
\text { Jeolla-do, } \\
\text { Korea }\end{array}$ & $\begin{array}{l}\text { - Variety and abundance of natural resource } \\
\text { - Devoted effort and commitment of fishing village community } \\
\text { members } \\
\text { - Continued resouree management system } \\
\text { - Active involvement with training program } \\
\text { - Logieal management }\end{array}$ \\
\hline $\begin{array}{l}\text { Jeodo } \\
\text { Commu } \\
\text { nity }\end{array}$ & $\begin{array}{l}\text { ido-dong, } \\
\text { cheon-si, } \\
\text { eongsang- } \\
\text { Korea } \\
\end{array}$ & $\begin{array}{l}\text { - Active participation of village people } \\
\text { - Timely development of target market with differentiated strategies } \\
\text { - Effective government support }\end{array}$ \\
\hline $\begin{array}{l}\text { Mira } \\
\text { Commu } \\
\text { nity }\end{array}$ & $\begin{array}{l}\text { Mira-ri, } \\
\text { Nohwa-eup, } \\
\text { Wando-gun, } \\
\text { Jeolla-do, } \\
\text { Korea }\end{array}$ & $\begin{array}{l}\text { - Maximization of profit through joint sales } \\
\text { - Increase in productivity by reorganizing fishery } \\
\text { - Rational shipping method } \\
\text { - Reinvestment of common profit } \\
\text {-Security of trust through transparent sales channel }\end{array}$ \\
\hline $\begin{array}{l}\text { Hota } \\
\text { Fishing } \\
\text { Village }\end{array}$ & $\begin{array}{l}\text { Kyonan-mae } \\
\text { hi, } \\
\text { Awa-gun, } \\
\text { Chiba pref., } \\
\text { Japan }\end{array}$ & $\begin{array}{l}\text { - Development that includes hinterlands of the fishing village } \\
\text { - New business model that combines primary and tertiary industry } \\
\text { - Profit generating through direet management of a restaurant by } \\
\text { fishermen, which also brings financial stability to fishin } \\
\text { households } \\
\text { - Increase in number of visitors due to new facilities to } \\
\text { accommodate group visitors }\end{array}$ \\
\hline $\begin{array}{l}\text { Hagi } \\
\text { Fishing } \\
\text { Village }\end{array}$ & $\begin{array}{l}\text { Hagi-shi, } \\
\text { Yamaguchi } \\
\text { pref.. Japan }\end{array}$ & $\begin{array}{l}\text {-Supply of fresh and safe marine products in spirit of chisanchisyou } \\
\text { (consumption of marine products using local natural resources) } \\
\text { - Sales of farm and livestock products in addition to seafood } \\
\text { - Slow-start strategy with steady advance } \\
\text { - Active promotion through exposure to media } \\
\text { - Strict low-cost prineiple in business }\end{array}$ \\
\hline \begin{tabular}{l|l} 
Irabu \\
Fishing \\
Village
\end{tabular} & $\begin{array}{l}\text { Irabujima, } \\
\text { Miyakojimas } \\
\text { hi, } \\
\text { Ok in a w a } \\
\text { pref.. } \\
\text { Japan }\end{array}$ & $\begin{array}{l}\text { - Development that makes the best use of unique geographical } \\
\text { conditions } \\
\text { - Use of highly motivated, local human resouree } \\
\text { - Elimination of unnecessary investment by turning daily life of } \\
\text { fishermen into tourism products } \\
\text { - Members of the fishery cooperative endeavor to improve service } \\
\text { quality through efforts such as acquiring qualification to guide and } \\
\text { train visitors }\end{array}$ \\
\hline
\end{tabular}

\section{Discussion}

\subsection{Analysis on Guidelines on Development} for Fishing Village as Tourist Sites

1) Tasks to be performed in advance for Fishing Village Tourism Development

Under Korean and Japanese law, fishery rights are held exclusively by fishermen living in fishing villages and cannot be transferred, divided, or modified. Therefore, reviving fishing villages that have recently suffered from economic difficulties but are contributing to the stable provision of food to nationals is one the government's important national policy tasks. These fishing villages perform a crucial role and in establishing plans to develop them as tourist sites, the following tasks should first be performed.

- Establishment of long-term project plans: Developing fishing villages as tourist destinations is a strategic business to lead the local economy (Park,
2002). As shown in some successful cases, therefore, it is important for the government to establish long-term strategies for the project and to give proper support to it when necessary(Jang,2005). Composite and systematic development plans should first be established from the dimension of utilizing coastal zones.

- Reasonable business operation: The assumption that fishing industry experts are managerial masters may be correct or incorrect. However excellent a business plan may be, if the fisherman cannot manage it, the possibility for the project to be successful is remote. Therefore, management styles in terms of tourism business operation should definitely be reviewed.

\section{2) Objectives and Direction of Fishing Village}

\section{Tourism Development}

Tourism development of fishing villages aims to create attractive fishing villages as tourist destinations that can be sustainably used. Therefore, plans should be made to improve relevant facilities for the purposes of realizing tourism potential, providing new and diverse services to tourists, and promoting regional development with the economic benefits arising from tourism development. Such benefits, including development-investment, employment, and tourism revenue, contribute to local environment and improve residents' lives. Detailed objectives of fishing village tourism development are as follows:

\section{(1) Creation of attractive fishing villages}

Among the various kinds of villages, fishing villages are special in their composition of sea and land, thus having a diversified ecology. This ecology is advantageous to the plan to change a fishing village into a tourism destination(Song, 2006). These fishing villages basically consist of the surfaces of the sea, including fisheries in the front, fishing ports as intermediary linking facilities that link fisheries with fishing villages at the back, and fishing village spaces as hinterlands(Kim, 2007). Reviewing city development of fishing villages, we find that ports have worked as the cores of cities that have been enlarged toward interior provinces. Because of this, there are many cultural and historical artifacts accumulated in fishing villages(Yokouchi, et al. 1998). In addition, since fishing villages have diverse tourism resources as shown in $<$ Table 2>, plans that are intimately linked with those tourism resources are necessary in order to actively 
express the attractions of the fishing village

On the other hand, to become a tourist destination, attractiveness and the perfection of tourism resources and goods are important(Park, 2002). Therefore development of fishing villages as tourist locations should be performed for enhancing the value of their tourism resources. To this end, it is necessary to increase the accessibility of natural and cultural tourism resources for tour and leisure activities and to maintain and improve accommodation facilities(Jang, 2005). In other words, development of fishing villages as tourist sites should be aimed at creating locations that enable tourists to meet their desires by establishing diverse kinds of facilities with tourism-related functions, using the cultural and natural tourism resources owned by fishing villages.

(2) Creation of fishing village spaces for the protection of resources and their sustainable utilization

Development of fishing villages as tourist destinations is conducted out within the nature and culture to be preserved, so the framework for sustainable development without damaging the regional environment should be applied. Another purpose for developing fishing villages as tourist sites lies in preempting impacts that may occur in tourist activities.

The direction for developing plans to attain the objectives above is as follows.

- Marine product markets in fishing villages provide fresh and inexpensive aquatic goods produced directly by the local villages, so they are important attractions for tourists. Fishing ports should be reorganized to increase productivity of marine goods, and plans to maintain their functions by introducing sustainable resource management systems should be implemented In addition to natural-resources dependent tourism, marine recreation facilities such as marinas, sea fishing facilities, and restaurants should be constructed to overcome seasonal variations and should be interoperated for space diversity.

- For fishing villages themselves to have tourism value, symbolic locations, parks, architecture, and monuments, including towers, should be built, and good view points and routes should be planned for activity spots. In particular, the effect of such place marketing is doubled by promotion activities. It is useful to promote, through media, a village's own identity, such as its traditional architectures and uniqueness (Oh, 2007).
To this end, the village's natural and cultural environment should be explored and preserved.

- Developing fishing villages as tourist destinations is a sustainable strategy because the local residents, not large outside investors, create and provide services for the tourists. In this way, the outflow of revenues is minimized, which facilitates economic sustainability (Bailey, 1996). In other words, tourist projects do not require large outside investments of capital and technology, but are highly efficient if local residents' participation is fully developed.

Table 3 Classification of Fishing Village Related Tourism Resources

\begin{tabular}{l|l|l}
\hline & \multicolumn{2}{|c}{ Names of tourism resources } \\
\hline \multirow{2}{*}{$\begin{array}{l}\text { Ratura 1 } \\
\text { Resources }\end{array}$} & $\begin{array}{l}\text { beaches, habitats for migratory birds, mud } \\
\text { flats, marine sport places(marina, yacht } \\
\text { places), coastal landscapes(national ocean } \\
\text { parks, sunrise / sunset watching places, } \\
\text { islands, strange rocks etc), sea fishing } \\
\text { locations }\end{array}$ \\
\hline \multirow{2}{*}{$\begin{array}{l}\text { Cultural } \\
\text { Resources }\end{array}$} & $\begin{array}{l}\text { Social/ } \\
\text { Cultural }\end{array}$ & $\begin{array}{l}\text { folklore halls,regional festivals, } \\
\text { sea foods, fishing gear and } \\
\text { fishing methods, historic } \\
\text { sites, fishing villages }\end{array}$ \\
\cline { 2 - 3 } & Industrial & $\begin{array}{l}\text { fishing ports, fisheries, fishing } \\
\text { boats }\end{array}$ \\
\hline
\end{tabular}

Source: Kim, S., 2007, chapter8, pp253-254

Even though the primary objective of fishing village tourism development is to enhance the local residents' life quality, not all the residents will consent to developing their villages for tourism and may resist a move to force tourism development. To reach a compromise, therefore, a council should be formed, which includes all interested parties such as community members, public servants, investors, and environmental groups. The council should discuss the scope and methods of development, and villagers should have priority in determining the direction of development projects.

3) Major factors for fishing village tourism development plan

Those fishing village tourism development factors that must be reviewed first based on the objectives and direction of fishing village tourism development are as follows.

- Continuity with hinterlands: Plan the development so that fishing villages and development areas are connected and unified without any severance. To this end, systematically consider the sizes, shapes, materials, 
and colors of the facilities.

- Multiplex land uses: Since simplified uses of land limited to certain functions or uses may keep land idle during periods other than the time, days of week, and seasons during which the functions or uses are provided, diversify uses and arrange facilities appropriately.

- Utilization of historical and cultural resources: In order to get away from uniform development with no competitiveness and to make unique fishing village spaces, restore and utilize historical and cultural resources.

- Securing accessibility. To enhance accessibility and to induce tourists to visit, expanded traffic infrastructure and an easily understood sign system is necessary. In addition, accesses from the land and accesses from the sea should each be considered and linked into a unified transportation networks.

- Environment conservation plan: Since fisheries resource are very important to fishing villages, development plans should be established within a limited range so as not to destroy the natural purifying ability of the village's ecosystem. If water areas must be unavoidably developed, the developer should first take mitigating action.

- Reclaimed land waterlines: If possible, protect the existing waterlines and plan reclaimed lands by using appropriate slow curves and bends, so that waterlines can be continuously viewed.

- Building plan: Plan waterside facilities to be low-rise and reserve sufficient open space at the waterside by forming parks and squares. In addition, establish view corridors from major public facilities and pedestrian spaces to the watersides.

\subsection{Guidelines for developing fishing villages} as tourist sites

The guidelines based on the successful cases described in Section 3.1 (see Table 1), as well as the major factors in Section 4 (Major factors for fishing village tourism development plan) about the objectives and direction of fishing village tourism development, are as follows.

Plans for land use

(a) Extensive development that damages fishing villages' identities, which have been established over a long time, should be avoided, and the land in each district should be reasonably divided and gradually developed.

(b) Marine product markets in the areas under development should be sized according to the local population and the neighboring areas, taking into consideration potential customers' purchasing power and consumption patterns.

(c) Shorelines and neighboring zones should have limited private development, and public facilities should be placed for easy access and good views.

(d) Some land should be reserved in order to control speculative land investment and to meet changes in tourist demand.

\section{Development of tourist resources}

(a) Tourist programs with a theme of experiencing the fishermen's daily routines - such as awareness of the environment, gathering seafood, and becoming a fisherman-should be planned so that the necessary investments are relatively small.

(b) Local specialties and native foods should be developed and commercialized with clean and fresh natural resources, and local festivals should be promoted to reflect cultural traditions so that local residents and visitors can participate together.

(c) Agricultural products from neighboring areas, as well as seafood, should be provided to visitors at reasonable prices.

(d) Alternative tourism that extends tourist seasons, which requires facilities such as piers, underwater observation towers, and fishing village museums, should be built, and events for family activities as part of family tour programs be provided.

(e) Structures with conservation value along fishing ports facilities should be restored and used; for example, breakwaters can be used as a tourist resource by fixing old resting areas and promenades.

Plans for views

(a) View zones should support the flow of continuity inherent in villages and physical and visual connection with them to promote integration between fishing villages and developed areas.

(b) Buildings should reflect each area's uniqueness.

(c) In refurbishing existing buildings, colors and designs suitable for the natural environment should be 
selected. New and manmade structures' colors should reflect their surroundings, and not be painted with conflicting colors.

(d) Buildings materials should be bricks and timbers that are nature-friendly over time. These materials will blend into the fishing villages' unique geographical and scenery characteristics. As for pavement materials, porous concrete, macadam, or sandy clay should be used with boundaries that match the adjoining spaces ${ }^{7)}$.

- Plans for resource protection

(a) Evaluation of environmental impacts should be performed when constructing new facilities, and the results should reflect whether the development should be halted or scaled down. Even after the completion of the facilities, a before and after comparison of the development should be carried out, so that restoration efforts can be done if the environmental damage is severe.

(b) Investigate and analyze desired demand for fishing village resources on a regular basis in order to limit the number of tourists and the amount of marine products they obtained.

(c) To minimize the possibility of over-development, demand from future local community members and visitors should be considered when building facilities.

(d) Areas with a high preservation value should be designated as "developmentally restricted."

(e) From the perspective of adaptive management, changes in resources should be monitored in order to review and modify relevant policies in case of problem occur.

Plans for operation and marketing

(a) Fishermen or their cooperatives should operate restaurants to provide their seafood harvested at inexpensive prices

(b) To operate fishermen's cooperatives in a fair and objective manner, core staff should be selected from outside, so that transparency and customer confidence in sales can be increased.

(c) To attract customers of different ages, diverse events such as recreational activities, shopping events, and history travels should be provided.

(d) The number of floors in a store makes a difference in sales, so the locations of stores should be changed on an annual basis to reduce this effect and prevent inside conflicts.

(e) Strict punitive regulations should be established as restraints on disruptive or illegal stores by ordering the suspension of business or depriving the business of their rights to operate.

(f) To maintain competitiveness, shift in demand by tourists should be monitored continually, and efforts should be placed on modernizing facilities and developing new products.

(g) As a government policy, aggressive marketing strategies such as low user fees for highways leading to fishing villages and reduced excise taxes for products in those villages should be adopted

\section{Conclusion}

Fishing village tourism development has become a new way to promote fishing villages and improve the quality of life in villages that have structural and economic problems. Moreover, the demand for fishing village tourism development is increasing, as changes in tourism occur and alternative tourism becomes more popular. However, fishing village tourism development faces problems due to the limited amount of capital investment and a lack of a vision for future development. To overcome these limitations and become a sustainable source of income for regional residents, this development should move away from tourism only and embrace a broader perspective.

This study examined characteristics and the current status of fishing village tourism development in Korea and Japan, summarize some successful cases, suggested tasks to be carried out for the development of fishing village tourism, and finally proposed a development guideline.

Developing fishing villages as tourist destinations is an important project, so that effects of developing tourism resources, tourist activities on the villages should be considered when reviewing plans ranging from the establishment of new facilities and their operations to the perspective of increasing each village's brand value. Basic plans for future fishing village tourism projects can be made based on the guidelines in this study.

7) Source: Ministry of Culture and Tourism(2006), Research on basic plans for a pilot project wishing Islands, p. 176 


\section{Acknowledgements}

I wish to express my gratitude to Hong, J. (Korea Maritime Institute) for his helpful comments on an early stage of this article. Thanks are extended to Nakasawa, S. (Hagi producer), Lee, B. (Jeodo village chief), Park, S. (Songgye village chief), Kang, D. (Sacheon City Hall), and members of Kondo and Yamamoto laboratory at Nihon University for their support.

\section{References}

[1] Bailey, C.(1996), "Sustainable Community Development through Coastal and Marine Tourism: Opportunities and Constraints", Proc. of the 1996 World Congress on Coastal and Marine Tourism, Vol. 6, pp. 31-37.

[2] Hwang, K., and Lee, S.(2000), Research on measures to activate fishing village tourism by inducing participation of local residents, Chapter3: Sustainable Fishing village tourism development and Community Participation, Korea Maritime Institute.

[3] Jang, E.(2005), The Theory and Actuality of the Experience Tourism, Baeksan, South Korea, p. 150.

[4] Kim, S., et al.(2001), Research on Fishing Village Tourism Development Programs by Type, Korea Maritime Institute, pp. 27-31.

[5] Kim, S.(2007), Introduction to Marine Tourism, Hyunhaksa, Seoul, South Korea, pp. 259-260.

[6] Korea Maritime Institute(2005), Research on Programs of Fishing Village Tourism Revitalization through Interactions between Cities and Fishing Villages, Ministry of Maritime Affairs and Fisheries of South.

[7] Kyonan Town, Chiba prefecture(2008), Hota Fishing Port Area Activation Plan.

[8] Lim, Y., et al.(2004), "The direction for development according to the actual condition of national tourism in fishery communities", Journal of Korean Tourism Research, Vol. 18, No. 2, pp. 309-322.

[9] Ministry of Maritime Affairs and Fisheries of South Korea(2007), Collection of Best Practices in Fisheries Industry and Fishing Village Projects, pp. 95-155.

[10] Ministry of Maritime Affairs and Fisheries of South Korea(2001) Research on Establishment of Midterm and Longterm Development Plan for Fishing Village Tourism, p. 21.

[11] Ministry of Maritime Affairs and Fisheries of South
Korea(2004), Research on Assessment and Effective Promotion of Overall Fishing Village Development Project.

[12] Ministry of Culture and Tourism(2006), Research on basic plans for a pilot project wishing Islands, p. 176.

[13] Nakasawa, S.(2007), Report of Hagi Sea Mart Business Model, Shoko Research Institute.

[14] Norinchukin Research Institute Co.,Ltd.(2007), The Present Conditions and the Problem of the Marine Products Market.

[15] Oh, C.(2007), International Symposium for Coastal Management and Community Development of Busan: Fishing Community Development, Coastal Recreation and Tourism as a Sustainable Community-based Economic Development Strategy in USA.

[16] Park, K., and Kim, H.(2002), "A Physical Planning Approach on the Specialization and Systematization of Tourism Resources: Focused on the Utilization and Development Potential of Tourism Site", The Korean Academic Society of Culture and Tourism, Vol. 4, No. 1, pp. 139-156.

[17] Song, G.(2006), Fishing Village and Tourism, Korea Research Information Center, Paju, South Korea, p. 20.

[18] Yokouchi, N., and Research of Waterfront Plan(1998), Planning Notes for Waterfront Development, Kyoritsu publishing, Tokyo, Japan, p. 6.

Received 2 September 2013

Revised 17 May 2014

Accepted 26 May 2014 